\title{
MIR34B Gene
}

National Cancer Institute

\section{Source}

National Cancer Institute. MIR34B Gene. NCI Thesaurus. Code C81764.

This gene is involved in the regulation of gene expression a plays a potential tumor suppressor role in colorectal carcinoma. 